\title{
Teaching through Experiential Learning Cycle to Enhance Student Engagement in Principles of Accounting
}

\author{
Rohaila Yusof*, Khoo Yin Yin, Norlia Mat Norwani, \\ Zuriadah Ismail and Anis Suriati Ahmad \\ Universiti Pendidikan Sultan Idris, Malaysia \\ https://orcid.org/0000-0001-5304-8970 \\ https:// orcid.org/0000-0003-4850-2184 \\ https://orcid.org/0000-0002-6795-906X \\ https://orcid.org/0000-0002-9721-3402 \\ https://orcid.org/0000-0002-4070-3398 \\ Salniza Salleh \\ Universiti Utara Malaysia \\ https://orcid.org/0000-0003-4518-7721
}

\begin{abstract}
This paper aims to investigate structuring classroom activities in experiential learning cycles to facilitate first-year Business and Accounting students' engagement in principles of accounting course. The levels of student engagement and achievement in understanding accounting concepts are measured at the end of the course. The content of fundamental accounting is structured into experiential learning cycles to provide a practical model for learning accounting concepts. Two models of students learning are tested in this study are the Kolb Experiential Learning Model and Burch Engagement Model. A quasi experimental study is implemented to test the effectiveness of an experiential learning model in improving student engagement. Lessons on Business Accounting is structured into an experiential learning cycle and delivered to an experimental group to measure the improvement in students' engagement. Burch Engagement Model which measures students' cognitive, emotional, and physical engagement is applied in measuring their engagement level. A pre and post-test design are employed to measure the difference in their engagement level between the control and the experimental group. The respondents of this study are a total of 112 students in Principles of Accounting course. Questionnaires and test sets are the measurement instruments used for data collection. After an eight-week exposure to experiential learning strategy, the post -test score for students' engagement show an increase in means of the four dimensions of student engagement, with the
\end{abstract}

* Corresponding Author: Rohaila Yusof, Email: rohaila@fpe.upsi.edu.my 
highest mean in the cognitive in-class engagement, followed by cognitive out-of class, physical and emotional engagement. Improvement in the cognitive score is concluded to be significant across the cognitive levels of Bloom Taxonomy mainly in understanding, application, and analysis. The implications of this study involve improvement of the support system to materialize the experiential learning strategy.

Keywords: Kolb Experiential Learning Strategy; Students Engagement; Business Accounting; Cognitive in-class Engagement

\section{Introduction}

The aspiration of the Ministry of Education in Malaysia through the Malaysian Educational Blueprint 2015-2025 aims to nurture entrepreneurial graduates with the attributes of financial sustainability. It is significant to improve the delivery of basic accounting courses to prepare students with basic financial management skills to choose and start their initiatives that align with nurture holistic graduates. The National Entrepreneurship Policy targets 15\% of graduates to become entrepreneurs.Thus, financial skills acquisition need to be strengthened to equip graduates with venture into their entrepreneurship process. Hence, the teaching methods in Higher Education Institutions in the field of accounting and management need to be enhanced. It is inevitable to mention that accounting is a significant concept in financial management to help these potential entrepreneurs in the act of planning, organizing, directing and controlling economic activities.One of the main financial activities in business includes the process of procurement and utilization of funds of the enterprise (Juneja, 2017), wherein specific accounting knowledge, skills and values are required. Unfortunately, reality reveals that many entrepreneurs have not taken this matter seriously to the degree that sales proceeds is used to fund their expenditures rather than to prioritize company needs.Indeed, studies on the failure of entrepreneurs of small and medium businesses also found that $83 \%$ of businesses failed due to cash flow management weaknesses (Arditi, Koksal \& Kale, 2000). This situation indicates the insufficient skill and level of awareness of financial management among entrepreneurs.

\section{Background of the Study}

Business Accounting course is one of the many names given to fundamental accounting courses offered in accounting degree programs to all accounting majors and non-majors in most HEIs (Higher Education Institutions). It comes under different names such as Introduction to Accounting, Principles of Accounting, and other terms that reflect the nature of the course as fundamentals and basic. Accounting is a field that requires a careful systematic approach to recording, reporting and analyzing diverse business transactions. Accounting subjects are often seen as more conceptual than procedural (Wyhe \& Arthur, 1991), and an excessive emphasis is on finance rather than accounting management (Roudaki, 2016). The course syllabus is specifically designed to provide students with basic knowledge in accounting, namely: technical classifications, recording transactions, and preparing financial statements. The 
Course Learning Outcomes (CLO) of the course is for students to prepare a full set of accounting and probably some additional generic skills incorporated into the course to meet the overall Programme Learning Outcomes (PLO). However, past research on students' achievement shows that students' achievement in the first accounting course is not convincing and dependents on various factors, especially prior learning experience (Garkaz, Banimahd \& Esmaeili, 2011) and students' interest and career aspirations (Kamaruddin, 2015). Students' achievement results from various interacting factors such as intellectual capacity, quality of delivery, motivation, learning approaches, students' socioeconomic factors, and other factors. Nevertheless, students' engagement could be one of the factors determining their retention (Ndege, 2010), skills development (Kapur, 2018) and student interest (Ghasemi, Moonaghi \& Heydari, 2018). Student engagement also includes comprehensive aspects of achievement besides cognitive, and cognitive engagement inside and outside the classroom. In this line of thought, Student engagement is a critical factor worth studying, as it is believed to drive students to work independently.Add to this, engaged students are expected to be inquisitive and carry their thinking beyond the classroom (Taylor \& Parsons, 2011). A close attempt by the quality assurance framework to measure student engagement is the compliance of 40 hours SLT for each credit assigned to a course, applied as the standard measurement in MQA. Various learning activities are suggested to fill the 120 hours SLT for a three-credit system, with the biggest portion on non-face-to-face learning. The SLT concept demands motivation, ability and monitoring of independent studies to take place among students.

Business accounting course has to be relevant and effective in preparing holistic graduates. The practical or hands-on method is believed to be the most effective delivery method for suitable classes. Thus, experiential learning is a method that could provide relevant in-class experience for better engagement among students. Fundamental Accounting course content ranges from technical book keeping skills to financial statement preparation, which requires analytical skills. The business examples used are often based on textbooks and less relevant to real business situations. The textbook approach is not effective in engaging students in learning, because students need to be engaged through meaningful and challenging activities to see the big picture of accounting skills in solving real problems. The study by Kraukuer, Serra and De Almeida (2017) found advantages regarding experiential learning in entrepreneurship learning, such as greater student engagement and a sense of empowerment. Students can apply knowledge management theories to their team experiences combining theory and practice and use them in their work (Pauleen, Marshall \& Egort, 2014). The AACSB Guidelines (AACSB,2013) strongly recommend applications of experiential learning in the business curriculum. It is more fitting to attain learning outcomes that require more successful areas or practical abilities such as strategic decision-making, coordination, leadership, collaboration and many other skills. 


\section{Literature Review}

Effective delivery methods provide new experiences to students to link existing knowledge to the desired knowledge. Learning is the process whereby knowledge is created through the transformation of experience (Kolb, 1984). Beard and Wilson (2002) stated that when receiving a stimulus, be it an external or internal one; a form of learning from experience is generated. Figure 1 represents the complex process of perception being interpreted and responded as an experiential learning process.

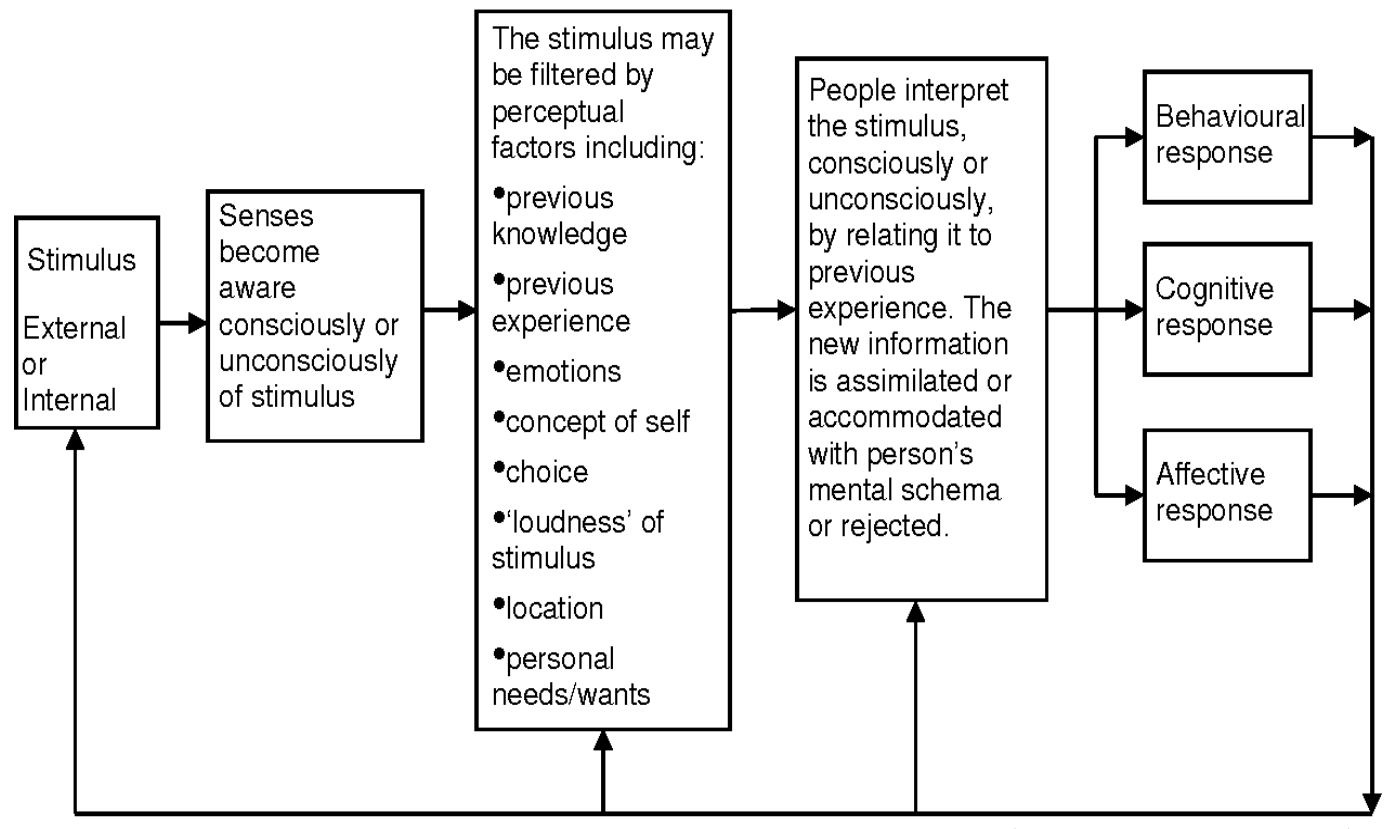

Figure 1. The process of perception and experiential learning (Beard \& Wilson 2002)

Kolb's(1984) learning cycle is an experience-based learning strategy in which each student should be given the opportunity to undergo the four phases of learning for each topic. Kolb Learning Cycle (1984) originates from a theory that learning style can be ranked along a continuum. Many studies attempted to show the relationship between learning styles and achievement, yet there is little evidence to support teaching according to individual learning styles as differences and preferences in the way individuals learn exist. Hence, a variety of experiences in learning provides students with a rich understanding of knowledge. Such a conception is elaborated and therefore different learning styles are met through the four cyclical phases namely: concrete /abstract, and experimental / reflection being organised in two-opposite continuum. Figure 2 reflects the four phases in respect to their continuum. 


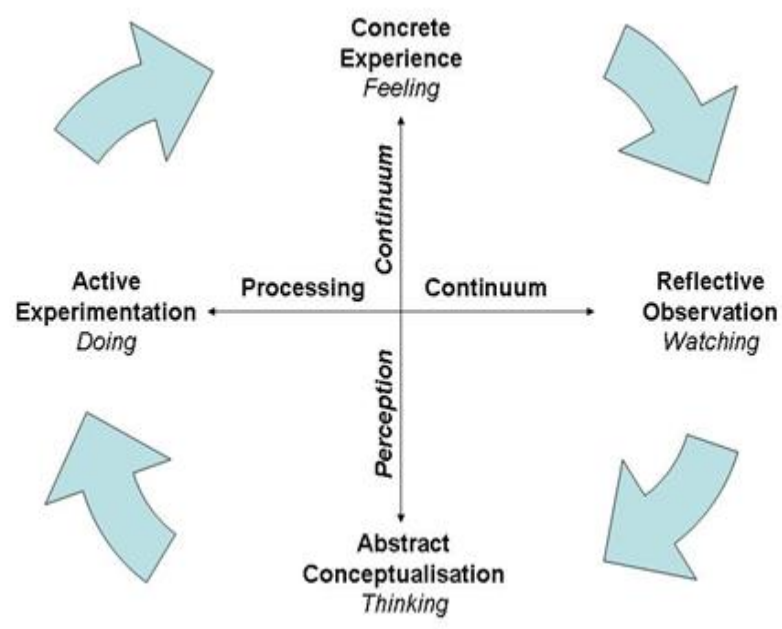

Figure 2. Kolb learning cycle

The Kolb learning cycle model (1984) is applied in learning Principles of Accounting by providing four different activities with related resources. Firstly, students need to understand the big picture, 'Why' to stimulate their interest in the subject matter, 'What' is the significance of this lesson to their everyday life, 'How' to understand the concepts and related theories. In return, students should apply the newly learned concept and ideas into a situation; that is the 'What if' phase. These four questions represent the learning cycle's internal structure which implies a pattern for learning new concepts. A combination of the learning modes from all four learning styles produces the highest learning level (Harb \& Terry, 1995). Among the teaching challenges in a cycle is preparing suitable materials to provide relevant experience. In another terms, each quadrant offers a learning experience that suits one out of four learning styles according to the Kolb Learning Styles Model (KLSM); assimilators, divergers, convergers, and accommodators. KLSM is based on how students perceive and process information in learning through two-opposite continuum; feeling and thinking in the perceiving continuum, while reflecting and doing is in the processing continuum.

The first quadrant refers to suitable activities to assimilate learning inclination through feeling and doing, such as motivational stories, group problem solving, etc. The second quadrant is for those who learn through feeling and watching, such as textbook reading assignments, seminars, etc. Whereas the third learning style assimilates who learn through thinking and watching, including field trips, group discussions, and the like. Finally, the fourth style consists of convergers that calls for who learn through reflection and doing, which is best supported by lectures with demonstrations, examples, problems, etc. These activities are not mutually exclusive; meaning that the same types of activities can provide a different learning experience. In this regard, educators can give various learning activities to offer small experiences in class for better student engagement. Table 1 indicates the type of learning activities to provide students with rich learning experiences (Harb \& Terry, 1995). 
Table 1. Learning activities for each quadrant

\begin{tabular}{l|l}
$\begin{array}{l}\text { FIRST QUADRANT LEARNING } \\
\text { ACTIVITIES }\end{array}$ & $\begin{array}{l}\text { SECOND QUADRANT LEARNING } \\
\text { ACTIVITIES }\end{array}$ \\
Motivational Stories & Formal lecture, thinking tone \\
Simulations & Lecture with Visual Aids \\
Class Discussion & Lecture with Programmed Notes \\
Group Discussion & Textbook Reading Assignment \\
Journal Writing & Problem Solving by Instructor \\
Brainstorming & Example Problem from Textbook \\
Interactive Lecture & Professional Meetings \\
Group Problem Solving & Large Seminars \\
Formal lecture, feeling tone & TV Demonstrations \\
Field Trips & Independent Research \\
Role-Playing & Objective Exams \\
Socratic Lecture & Library Searches \\
Group Experiments & Gathering Data \\
Subjective Tests & \\
THIRD QUADRANT LEARNING & FOURTH QUADRANT LEARNING \\
\multicolumn{1}{c}{ ACTIVITIES } & ACTIVITIES \\
Example Problems Worked by & Open-Ended Problems \\
Students & Open-ended Laboratories \\
& Student Prepared Problems \\
Homework Problems & Field Trips Student Presentations \\
Guided Labs & Semester Long Design Projects \\
Computer Simulations & Socratic Questioning \\
Field Trips & Group Discussion \\
Objective Exams & Student Lectures \\
Laboratory Test & Brainstorming \\
Individual Reports & Role-Playing \\
Computer-Aided Instruction & Subjective Exams \\
Lectures with Demonstrations & Think Tanks \\
& Simulations \\
Group Problem Solving \\
Group Projects/Reports \\
\end{tabular}

Source: Harb and Terry (1995)

Based on four chapters in the accounting syllabus, namely: budgeting, bookkeeping, cashflow, and profit and loss statement, a comprehensive approach is presented by utilizing all 4 phases of the Kolb Learning Cycle. Figure 3 illustrates the cycle for the first chapter, which is budgeting. For the first quadrant, Concrete Experience (CE), known as the "Why" phase, students are exposed to business failure due to failed budgeting. Taking the case of Muslim Awang, the students go through the 'big picture' before answering six reflective questions in the second quadrant, the so-called the "What" phase. Moving on to the third quadrant, Active Experimentation (AE), students are provided with complimentary notes on budgeting before preparing a budget of Muslim plans to set another branch up in the campus with more students in the last quadrant (Concrete Experience (CE).). 


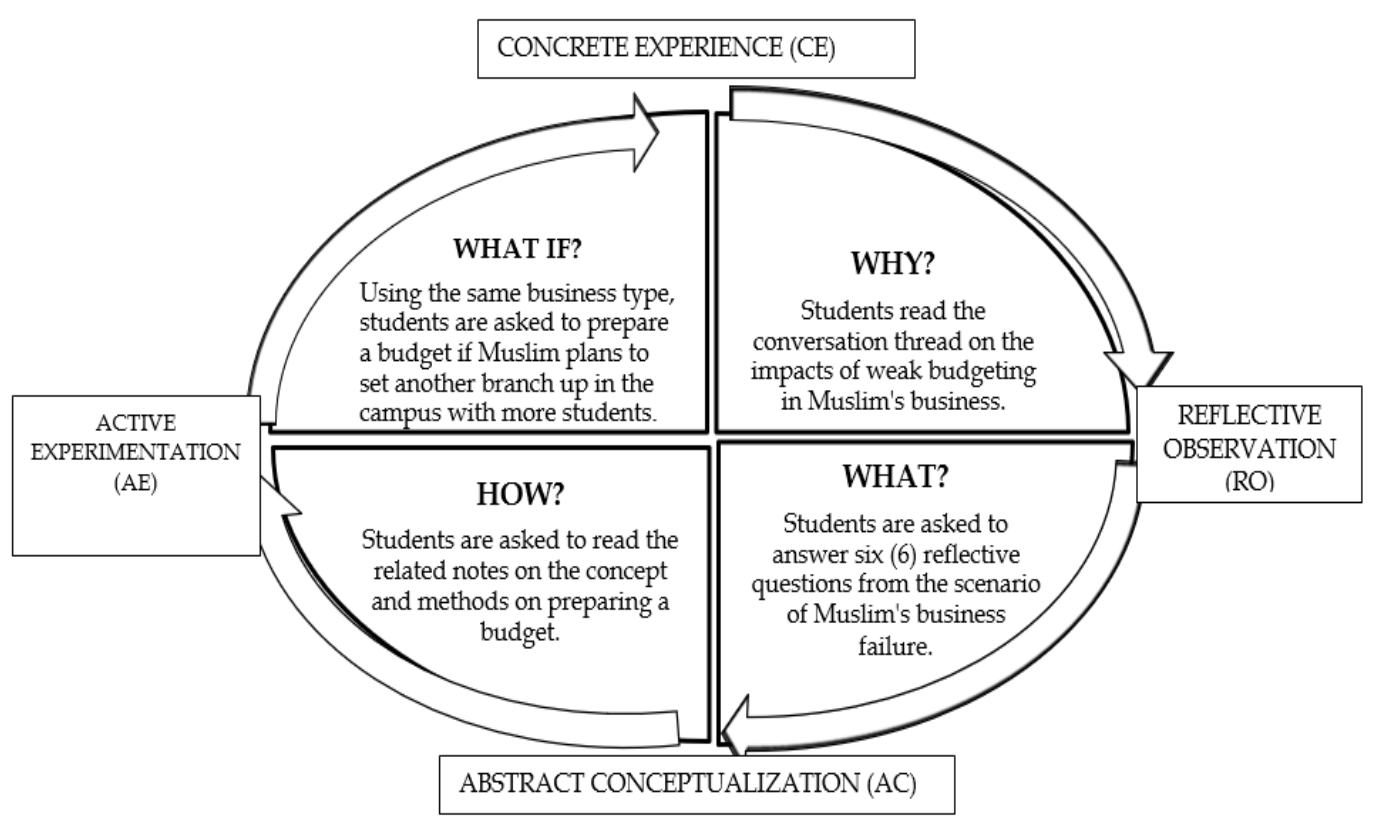

Figure 3. Kolb learning cycle for budgeting

Figure 4 depicts the Kolb Learning Cycle for the second chapter, which is bookkeeping. The Concrete Experience (CE) or the "Why" phase engages the students through a news article and role-plays on Pn Husna, who owns a bakery, and her business partners. For the Reflective Observation (RO) quadrant, students must answer several reflective questions for all three scenarios.In this context, students are supplied with notes on bookkeeping being discussed in class for the "How" phase or Abstract Conceptualization (AC). Lastly, students are required to prepare bookkeeping for bigger scale bakery business by Pn Husna.

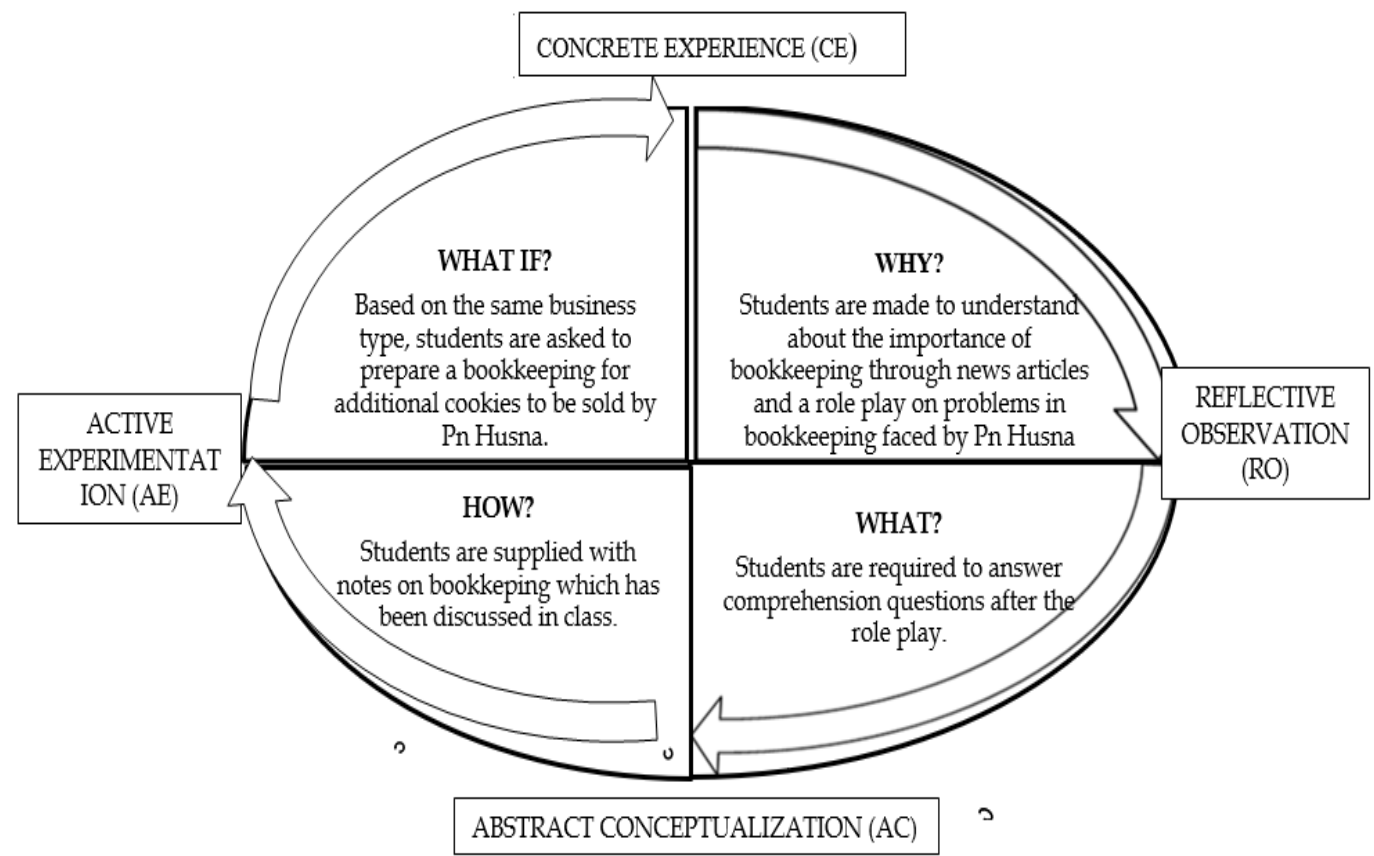

Figure 4. Kolb learning cycle for bookkeeping 
Figure 5 respectively shows the Kolb Learning Cycle for the preparation of cash flow.The use of interactive stimuli for the Concrete Experience (CE) is manifested through cafe businesses' video. Next, the students are expected to reflect on four issues surrounding Bob and his newly-opened cafe "The Wired Cup" for the Reflective Observation (RO) phase. Using the journal articles and presentation slides in the Abstract Conceptualization (AC), students will gather the necessary knowledge to prepare a good cash flow to help Bob increase the revenue while minimizing the costs simultaneously for the last quadrant, Active Experimentation (AE).

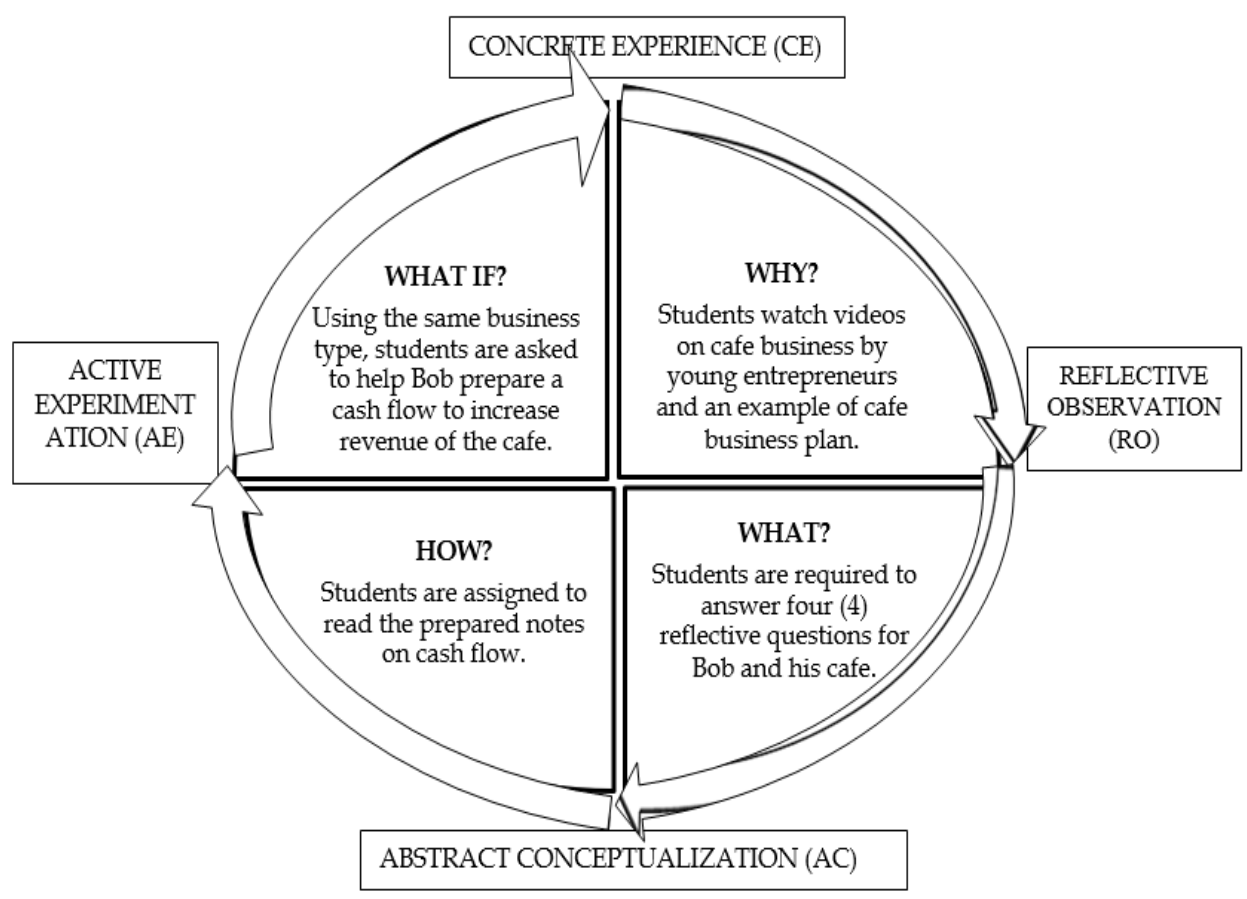

Figure 5. Kolb learning cycle for cash flow

Figure 6 below explains the Kolb Learning Cycle for the fourth chapter, the profit and loss statement.In the first quadrant or the "Why" process, students are introduced to the circumstances of a stall owner who does not manage to figure out where the profit has gone even though their profits are increasing. Moving on to the next quadrant, namely the Reflective Observation (RO) or the What step, they are invited to give their opinions and perspectives on the respective issues based on various thought-provoking questions. In the third quadrant, the Abstract Conceptualization (AC) or the How to process, they are expected to read the necessary materials, such as textbook notes and presentation slides in hope to solve problems in the last quadrant, Constructive Exploration (AE) or "What If" process. 


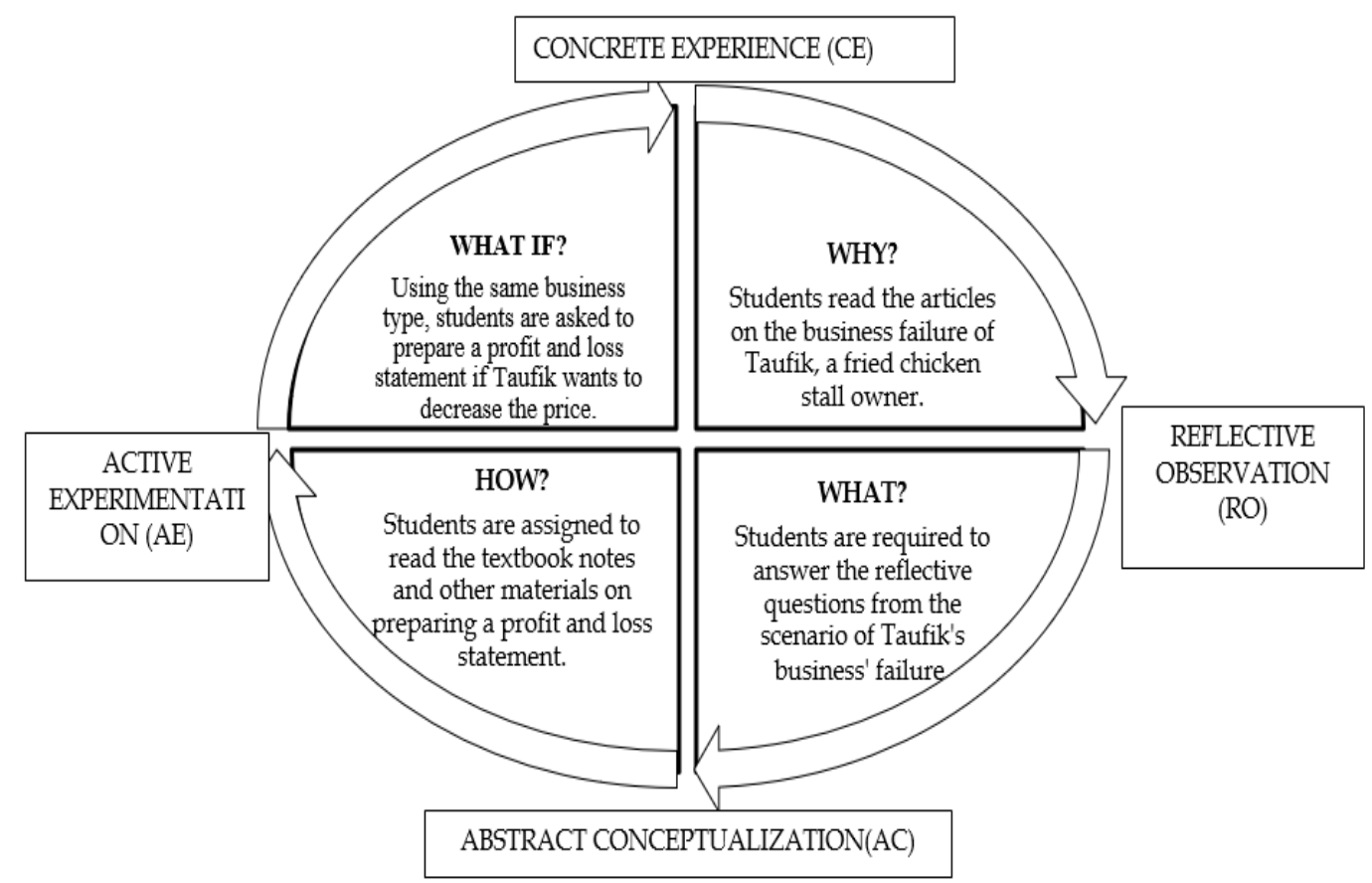

Figure 6. Kolb learning cycle for profit and loss statement

The activities put forward befit the definition of experiential learning which stands on an interdisciplinary approach based on management, education, and psychology, and implicating a holistic process of action/reflection built on experience/abstraction (Kolb \& Kolb, 2005). Past research in applying experiental learning models in entrepreneurship and business education results in positive learning outcomes achievement, measured by the Students Course Experience Scale (Yusof et al., 2019).

One of the expected outcomes of experiential learning is student engagement which is defined as the interaction between time, effort, and other resources invested by students and institutions to optimize students' experiences and increase learning outcomes for their performance development and institutional reputation (Trowler, 2010). Efforts towards student participation can be seen through a diversified pedagogical approach to attracting and unburdening accounting topics, including activity-based courses, sports, internet studies, and computer simulations that combine to enable students to learn through real-time accounting circumstances (Jaijaram, 2012). The ability for students to learn by experience is recognized by AACSB (2013), which defines experiential learning as one of the meaningful means of engaging students.

\section{Methodology}

This research is a quasi-experimental study which is used to study relevant teaching and learning materials development to enhance students' engagement. Quasi-experimental research involves the manipulation of an independent variable without the random assignment of participants to conditions or orders of conditions. In this research paper, the researchers have implemented Kolb 
learning cycle which takes eight weeks. 112 first-year students in Business Accounting field are selected to participate in this study. In hope to meet the aim of this study, important modifications are done on the course outline to ensure that the class activities focus on enhancing students' experiential learning. The T\&L tasks are conducted differently where students have to go around the loop in a clockwise direction in which the treatment group receives the intervention (Kolb learning cycle) of learning in a process while participants in the control group go through the usual lecture and demonstration method. A pre-test questionnaire and a test set are designed and administered to students from the Business Accounting course, in which the pre-test consists of a test set with 24 item questions on students' engagement and a test set of 9 items on existing knowledge of business accounting. The same set is repeated to students as a post-test after the intervention. At the end of the cycle that takes eight weeks, 24 hours of lessons, students' level of engagement is measured using a 24-item scale adapted from Burch et al. (2015) who proposed a conceptualization of student engagement grounded in A. W. Astin's Student Involvement Theory and W. A. Kahn's employee engagement research where student engagement is built on four components: emotional engagement, physical engagement, cognitive engagement in class, and cognitive engagement out of class.

Early findings indicate that students put a significantly high amount of time and energy on experiential learning, which leads to increased engagement in feeling and cognitive continua. On the other hand, classical instructional approaches are effective if one finds the exam score to be the final learning indicator. Exam score and drilling are successful opportunities to improve thinking abilities, such as analytical skills in accounting. Four main topics in Business Accounting are delivered through the Kolb Learning Cycle (KLC). The topics are as follows: I Budgeting, II. Bookkeeping, III. Cash Flow, IV. Profit and Loss. These four topics are delivered in four different cycles in eight (8) weeks.

\section{Findings}

The goal of the paper is to create a Business Accounting course in an experiential learning loop that could offer a realistic model for learning fundamentals in acco unting for entrepreneurs. It is assumed that as a lesson is prepared, it will address Why, What, How, and What if that improves students' learning and increases their engagement. Each additional loop should be in the target position to offer deeper awareness and dedication to lessons. This research believed that experiential learning could contribute to student participation and therefore improve achievement of learning outcomes. The course helps students to demonstrate the practical knowledge of learning fundamentals in accounting for entrepreneurs and improve their application of accounting experience in entrepreneurship through physical, emotional, and cognitive engagement. Business accounting content is grouped into four main topics designed into experiential learning cycles to maximize students' learning experience. Understanding why the issue is important motivates them to know more. Going through the quadrant of concrete experience provides students with a big picture which helps them see the topic's importance. The 'Why' quadrant offers actual cases and circumstances for students. Next,the students learn through 
their reflections of the big picture through the cases provided. Reflection is shown to be a good engine of learning. Instructors prepared significant leading questions to direct students through reflections.

For example, answers such as, "business fail because the owner did not anticipate steep competitions from other food outlets that would cause him to lose sales volume, should therefore provide more variations or extend business hours to be competitive. Students directly relate their perceptions and information to the lecture. In the meantime, engagement is at an emotional level. The students' answers show that they even discuss the issue after class. Out-ofclass discussions strengthen cognitive engagement through the "How" quadrant. The latter is the core concern of the syllabus and resources suggested by the instructors. Emotionally engaged students find more examples and ask questions about the new information they have discovered.The 'What if' quadrant would take the students to what happens if any action is taken, and a simulation of the predicted outcomes if any changes are made. The fourth quadrant requires students to gather information from reliable sources. At the end of the course, students' engagement is measured using Burch's (2015) Model of Engagement, which has three sub-dimensions: physical, emotional, and cognitive.

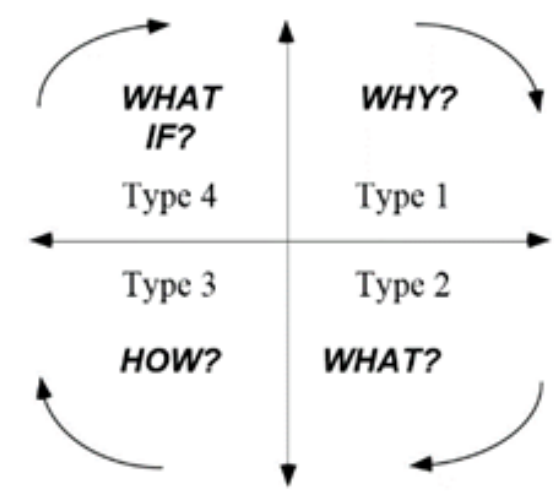

Figure 7. Four phases of the learning cycle.

Measurement of cognitive achievement is done through a test set consisting of three cognitive ability levels, understanding, application, and analysis. This study applies four dimensions of student engagement, considering the nature and limitations of the students' experience to go through in this teaching cycle. There is a difference in the level of engagement among the students after the intervention. Simultaneously, there is an improvement in the cognitive score for all three cognitive levels, understanding, application, and analysis. Findings of this study conclude that experiential learning activities provide an opportunity for students to demonstrate practical knowledge in accounting, and students are physically, emotionally, and cognitively engaged while learning through the various phases of experiential learning.

Table 1 indicates the difference in means for the four areas of students' engagement. The largest mean is for physical engagement (mean 4.21, n.d. .42), 
cognitive in-class engagement (mean 4.20, n.d. .46), cognitive out-of-class engagement (mean 4.20, n.d. .47), and mental engagement (mean 4.14, n.d. .51). There is a small increase recorded in the four dimensions of student participation; cognitive in-class (.37), cognitive out-of-class (.33), physical (.31), and emotional involvement (.30). There are also educational tools available to educators, such as cases and challenges with developing teaching and learning practices. As a consequence, educators using traditional teaching strategies may, at some stages, use tools that provide an opportunity for students to experience one or more of the four experiential learning quadrants. The results are confirmed by Kraukuer, Serra, and de Almeida (2017), who observed greater student participation and a sense of empowerment. Similarly, Pauleen, Marshall and Egort (2014) found a complete learning experience by integrating theory and practice through experiential learning.

Table 2. Domains of students' engagement

\begin{tabular}{llll}
\hline Domains of student engagement & \multicolumn{2}{c}{ Pre-test } & \multicolumn{2}{c}{ Post-test } \\
& Mean & s.d. & Mean \\
\hline
\end{tabular}

\section{Cognitive-in class}

I am interested in the material I learn in this class/course.

$\begin{array}{llll}3.83 & 0.79 & 4.27 & 0.53\end{array}$

I am excited about coming to this

class/course.

$\begin{array}{llll}3.73 & 0.86 & 4.28 & 0.52\end{array}$

When I'm in the classroom for this

lesson/course, I pay a lot of attention to class

4.01

0.58

4.23

topics and events.

I use the knowledge and skills I have gained from this class/course to deal with other students studying in the classroom.

I often explain course material to one or more students for this class/course.

I've memorized the course materials for assignments and exams in this class/course.

This class/course taught me to think objectively and analytically.

$\begin{array}{lll}0.32 & 4.23 & 0.46\end{array}$

\section{Cognitive-out of class}

I exert my full effort towards this

class/course.

I connect learning in this class/course to societal problems or issues.

$\begin{array}{llll}3.82 & 0.32 & 4.22 & 0.43\end{array}$

I reviewed my notes after class in this class/course.

$\begin{array}{llll}3.74 & 0.81 & 4.21 & 0.52\end{array}$

This class/course allowed me to learn challenging real-world problems. 
Physical

I am working with passion on assignments for this class/course.

$\begin{array}{llll}3.87 & 0.41 & 4.10 & 0.35\end{array}$

I feel positive about the assignments I have completed in this class/course.

$\begin{array}{llll}3.91 & 0.53 & 4.21 & 0.45\end{array}$

I work harder than I thought I could meet the instructor's expectations in this class/course.

$\begin{array}{llll}3.92 & 0.43 & 4.12 & 0.35\end{array}$

I work harder to produce good products in this class/course during difficult assignments.

$\begin{array}{llll}3.91 & 0.69 & 4.42 & 0.53\end{array}$

\section{Emotional}

I am enthusiastic about this class/course.

When I'm in this class/course, I feel energetic.

I sometimes ask questions or add to a class/course debate.

0.83

I discussed class/course topics, ideas or concepts with friends outside of class.

I have drawn results based on my study of numerical knowledge (numbers, tables, figures, etc.) in this class/course.

I used numerical information to examine a real-world problem or issue in this

This class/course helped me speak clearly and effectively.

This class/course helped me work effectively with others.

Table 3. Total difference of means and standard deviation.

\begin{tabular}{|c|c|c|c|c|c|}
\hline \multirow[b]{2}{*}{ Domains of student engagement } & \multicolumn{2}{|c|}{ Pre test } & \multicolumn{2}{|c|}{ Post test } & \multirow{2}{*}{ Difference of mean } \\
\hline & Mean & s.d. & Mean & s.d. & \\
\hline Cognitive-in class & 3.83 & 0.62 & 4.20 & 0.46 & 0.37 \\
\hline Cognitive-out of class & 3.87 & 0.51 & 4.20 & 0.47 & 0.33 \\
\hline Physical & 3.90 & 0.52 & 4.21 & 0.42 & 0.31 \\
\hline Emotional & 3.84 & 0.86 & 4.14 & 0.51 & 0.30 \\
\hline
\end{tabular}

Table 4 displays the test score on comprehension of the basics of financial management for entrepreneurs. There is growth in the cognitive score for all three cognitive stages, understanding (13\%), application (25\%) and analysis $(15 \%)$.

Table 4: Test score on students' knowledge

\begin{tabular}{lccc}
\hline Types of questions & Pre-test score (\%) & Post-test score (\%) & Difference (\%) \\
\hline Understanding & 70 & 83 & 13 \\
Application & 35 & 60 & 25 \\
Analysis & 45 & 60 & 15 \\
\hline
\end{tabular}




\section{Conclusion, limitations and Recommendations}

This study attempts to adapt to the Kolb Learning Cycle Model to design lessons for Business Accounting. Four main topics areorganized into four different cycles, which provide a different learning experience for the students. Students participate in the four learning cycles and are offered alternative ways of perceiving and processing the information. The materials used for the lessons play an important role in engaging the students. Students will receive current and popular types of business as stimuli because of their familiarity and interest in the subject. Awareness of the 'Why' do I have to learn this sub-topic becomes the driver for students to further understand. The stimulus must be relevant and current to make students curious enough to do further research and discussions on the subject matter. Variation of experiential learning programs can offer more opportunities for participation, such as fieldwork and on-site learning. Improving students' engagement, particularly on emotional and cognitive outof-class engagement make the learning process more productive. The quadrant of What is an important reflection in which educators direct students through their reflections. Answers given by students demonstrate their thinking and the ability for educators to know their previous understanding of the subject. In the 'How' quadrant, showing students notes and slides allow them to get a better idea of the relevant topics. The 'What if' quadrant allows them the to apply their experience from the three preceding quadrants to one major implementation of practical situations customised to brief problems or case studies.These activities can be unstructured, where students have to justify their acts.

Business Accounting is an applied functional subject that should be delivered in a practical way. Creating an environment in the classroom is a way to address time constraints and opportunities for students to do field study or work-based learning. The limitations of this analysis are the number of samples involved. Extending the study to other HEIs would serve to make the results of this study more effective. Another study area to be discussed will be applying the experiential learning approach to online learning for more analysis. Wellplanned experiential learning lessons can be provided by online learning leveraging multimedia tools that are more attractive to the $\mathrm{z}$ generation. The implications of this research is the support a sound framework for the introduction of an experiential learning approach. Flexible scheduling of classes will provide enough time for class events. A strong internet connection for connecting online services as part of the classroom experience is important.

\section{Acknowledgement}

This study was supported by UPSI Teaching and Learning Innovation Grant (GPU) 2017-0255-107-01.

\section{References}

AACSB. (2013). Eligibility procedures and accreditation standards for business accreditation. Tampa, FL.

Arditi, A., Koksal, A., \& Kale, S. (2000). Business failures in the construction industry. Engineering, Construction, and Architectural Management, 7(2), 120-132. 
Beard, C., \& Wilson, J. P. (2002). The power of experiential learning: a handbook for trainers and educators. Kogan Page Limited, London.

Burch, G. F., Heller, N. A., Burch, J. J., Freed, R., \& Steed, S. A. (2015). Student engagement: Developing a conceptual framework and survey instrument. $\begin{array}{llll}\text { Journal of Education for Business, 90(4), 224-229. } & \text {. }\end{array}$ https://doi.org/10.1080/08832323.2015.1019821

Garkaz, M., Banimahd, B., \& Esmaeili, H. (2011). Factors Affecting Accounting Student's Performance: The Case Of Students At The Islamic Azad University. Procedia Social and Behavioral Sciences, 29, 122-128. https://doi.org/10.1016/j.sbspro.2011.11.216

Ghasemi, M. R., Moonaghi, H. K., \& Heydari, A. (2018). Student-related factors affecting academic engagement: A qualitative study exploring the experiences of Iranian undergraduate nursing students. Electronic physician, 10(7), 7078-7085. https://doi.org/10.19082/7078

Harb, J. N., \& Terry, R. E. (1995). Application of the Kolb Learning Cycle to Design Instruction. ASEE Rocky Mountain Section Meeting, Golden, Colorado.

Juneja, P. (2017). Management Study Guide. Retrieved from https://www.managementstudyguide.com/financial-management.htm

Kamaruddin, R. (2015). Hubungan faktor pendidikan dan persekitaran dengan aspirasi kerjaya perakaunan dalam kalangan pelajar di negeri Pahang (Master's thesis). Universiti Pendidikan Sultan Idris.

Kapur, R. (2018). Factors Influencing the Students' Academic Performance in Secondary Schools in India. Retrieved from https:// www.researchgate.net/publication/324819919_Factors_Influencing_the _Students Academic_Performance_in_Secondary_Schools_in_India

Kolb, A. Y., \& Kolb, D. A. (2005). Learning styles and learning spaces: Enhancing experiential learning in higher education. Academy of management learning $\mathcal{E}$ education, 4(2), 193-212.

Kolb, D. A. (1984). Experiential Learning: Experience as the Source of Learning and Development. Prentice-Hall, Englewood Cliffs, N.J.

Kraukuer, P. V. D. C., Serra, F. A. R., \& de Almeida, M. I. R. (2017). Using experiential learning to teach entrepreneurship: a study with Brazilian undergraduate students. International Journal of Educational Management, 31(7), 986-999.

Ndege, T. (2010). Students' Engagement and Student Retention in Moi University, Kenya. Global Business and Economics Anthology, 2, 247-257.

Pauleen, D. J., Marshall, S., \& Egort, I. (2014). ICT-supported team-based experiential learning: Classroom perspectives. Education+ Training, 46(2), 90-99.

Roudaki, J. (2016). Undergraduate accounting programmes in developing countries: The case of Iran. Australia: University of Wollongong.

Taylor, L., \& Parsons, J. (2011). Improving Student Engagement. Current Issues in Education, 14(1). Retrieved from http://cie.asu.edu.

Trowler, V. (2010). Student engagement literature review. York: The Higher Education Academy.

Wyhe, V., \& Arthur, G. (1991). The accounting curriculum in higher education: A study in educational policy. University of Washington: ProQuest Dissertations Publishing.

Yusof, R., Yin, K. Y., Ahmad, A. S., Halim, H., \& Norwani, N. M. (2019). Students Course Experience: Reflections of Outcome- Based Education Implementation in Accounting Programmes in Higher Education. International Journal of Academic Research in Progressive Education and Development, 8(2), 228-238. 